\title{
Aisthesis
}

Firenze University Press

www.fupress.com/aisthesis

OPEN ACCESS

Citation: C. Froio (2021) To Brecht and Back. Notes on Clement Greenberg's Avant-Garde and Kitsch. Aisthesis 14(1): 153-163. doi: 10.36253/Aisthesis- 12054

Copyright: (c) 2021 C. Froio. This is an open access, peer-reviewed article published by Firenze University Press (http://www.fupress.com/aisthesis) and distributed under the terms of the Creative Commons Attribution License, which permits unrestricted use, distribution, and reproduction in any medium, provided the original author and source are credited.

Data Availability Statement: All relevant data are within the paper and its Supporting Information files.

Competing Interests: The authors have declared that no competing interests exist.

\section{To Brecht and Back. Notes on Clement Greenberg's Avant-Garde and Kitsch}

\author{
Camilla Froio \\ Università degli Studi di Firenze \\ camilla.froio@unifi.it
}

\begin{abstract}
Clement Greenberg's international reputation is partly due to the success of one of his first and most perceptive essays, Avant-Garde and Kitsch, published in the Fall 1939 issue of "Partisan Review". Despite its unsurpassed importance, the article still requires a broader comprehension of its origins: according to Greenberg's personal papers, the essay's main concepts began to take form during the Winter 1939, when the author was involved in the drafting of a new essay on Bertolt Brecht, still unpublished today, at that time submitted to the "Partisan Review"'s editorial board but rejected. A second document enables to trace back Avant-Garde and Kitsch's roots even further: according to a letter by Greenberg, one of the editors, Dwight Macdonald, plagiarized the rejected script as his last essay, Soviet Society and Its Cinema, clearly seemed to prove. The varied topics articulated in the letter, as well as in the draft on Brecht, would be at the basis of Avant-Garde and Kitsch, becoming crucial and early components of the editorial process of the well-known essay.
\end{abstract}

Keywords: Clement Greenberg, Avant-Garde and Kitsch, Bertolt Brecht, Dwight Macdonald, Marxist Criticism.

\section{INTRODUCTION}

After eighty years since its first publication on "Partisan Review" in 1939, Clement Greenberg's Avant-Garde and Kitsch is still regarded as one of the most influential essays of the twentieth century. By addressing urgent cultural concerns, the text's resonance moved far beyond the confines of the New York intellectual community and immediately reached the European shores. Still today Greenberg's work is surrounded by attention and interest: it is not an exaggeration to state that Avant-Garde and Kitsch has now achieved the high canonical status of a classic (Decter et al. [1986]; Ostrow [1989]; Greenberg, Schneller [2017]: 226). Through the elaboration of the essay's main thesis, that is the dialectical relationship between popular culture (kitsch) and avant-garde, Greenberg already developed the vocabulary and the conceptual framework of his model 
of thinking and writing. In a sort of way, with Avant-Garde and Kitsch the author already outlined the main direction of his future criticism, making this essay a paradigm of his critical and aesthetic perspective.

The historical and ideological context in which Greenberg's ideas flourished was deeply influenced by Marxist theory, which provided the main intellectual criteria for the evaluation and revaluation of twentieth-century cultural development (Clark [1961]: 71-73; Greenberg, Schneller [2017]: 19-21). From the second half of the 1930s, "Partisan Review" became one of the chief publishing forums for the Leftist intellectuals and a lively context for debate, especially during the war years (Orton, Pollock [1981]: 211-219; Gilbert [1968]; Bloom [1986]; Cooney [1986]; Wald [1987]; Froio [2018]: 30-38). At that time, the journal espoused a particular ideology by openly advocating Leon Trockij's intellectual and political stances, a disposition that was especially enforced after the Moscow trials, when the revolutionary was sentenced to death (1936-1937) ${ }^{1}$. Greenberg's initial formation as a Marxist art critic should be considered against the backdrop of his early years as a contributor for "Partisan Review" between 1939 and 1942: the journal was the primary vehicle through which the young writer's ideas were introduced to the American, then the European, Inteligencija (Clark [1961]: 71-74; NoyesPlatt [1989]; Rubenfeld [1997]: 42-67; Noyes-Platt [1999]: 239-250; Goldfarb Marquis [2006]: 33-34, 48-58). Avant-Garde and Kitsch, published in the Fall 1939 issue, at the very outset of Greenberg's collaboration with "Partisan Review", has its roots in the debates and commitments of the 1930s, becoming the visible product of a peculiar histori-

\footnotetext{
1 "Partisan Review" formalized its ideological alliance with Trockij by publishing Art and Politics in Our Epoch (formerly known as Art and Revolution), an essay written by the Russian revolutionary (August 1938), and Towards a Free Revolutionary Art (translated by Macdonald, Fall 1938), a manifesto signed by Diego Rivera and André Breton but strongly based on Trockij's reflections and observations on the revolutionary role of art. See Trockij, Siegel (1972): 104-114, 115-121.
}

cal circumstance: the paper discussed many of the issues at the core of "Partisan Review"'s cultural agenda of those years, especially the shared concern about the emergence of an insidious counterculture, reinforced by the totalitarian regimes, the one that Greenberg later identified with the word kitsch (Noyes-Platt [1999]: 87-159).

The principal aim of the present study is to open Avant-Garde and Kitsch to a different form of close interpretation and analysis, strongly based on the critical survey of Greenberg's personal papers held by the Getty Research Institute, Los Angeles (California). The paper especially seeks to address problems and issues related to the essay's genesis and editing process: through questioning the archival materials, it becomes possible to form a clearer picture of both the intellectual and the physical development of the essay. Alongside this central intent stands an additional one, which is the purpose of providing a firm textual basis for a better understanding of Greenberg's methodology at the very beginning of his debut as an art critic.

\section{A NEW ESSAY ON BERTOLT BRECHT}

(1938-1939)

At the end of the Thirties, Greenberg's interest in the so-called ersatz culture was encouraged by the high resonance of Kurt London's volume, The Seven Soviet Arts, published in 1938 and soon reviewed by Dwight Macdonald, one of the editors of "Partisan Review" (Macdonald [1939]); at the same time, Greenberg's concern was inspired and vitalized by his personal passion for Bertolt Brecht's poetry. As it is commonly known, the critic reached a turning point in his career with the publication of a brief review of Brecht's A Penny for the Poor (also known as the Threepenny Novel, the English translation of the Dreigroschenroman, first published in 1934, then translated in 1937), that appeared on "Partisan Review" in the Winter 1939 issue (Greenberg [1939a]; Clark [1961]: 73-74; O’Brian [1988]: XVIIIXIX). But, as the critic's personal correspondence points out, the beginning of the work on Brecht 
can be traced back to the early Thirties: in a letter date-stamped May 2, 1933 and addressed to a close friend, Harold Lazarus, Greenberg confided his desire to write a short story on Brecht's life: «I have an idea for a good story - the Nazi ransacking Brecht's apartment, then Brecht in the RR station about to take a train to Bodensee in Schweiz. But to appreciate the idea you'll have to read the two Versuche, I and II, that I read» (Greenberg, Van Horne [2000]: 92-93). This passionate involvement in Brecht's works seemed to be inspired by a sudden interest in Oswald Spengler's cultural pessimism: between December 1931 and October 1932, Greenberg focused his attention on The Decline of the West (Der Untergang des Abendlandes, 1918-1922) and on Man and Technics (Der Mensch und die Technik, 1931) (Greenberg [19281932]; Jones [2005]: 79). According to a second letter, date-stamped April 1, 1933 and a third one, May 2, both addressed to Lazarus (Greenberg [1933-1937]), Greenberg had already begun to outline an article on Brecht's poetry, which remained, as we may presume, incomplete. Few years later, thanks to his new friendship with Macdonald, who was introduced to him by Harold Rosenberg (O’Brian [1988]: XXI; Rubenfeld [1997]: 51; Goldfarb Marquis [2006]: 37, 48-51), Greenberg finally had the chance to publish the aforementioned review of Brecht's A Penny for the Poor, the critic's very first piece for "Partisan Review". The connection between Greenberg's personal ideas about Brecht's literature, developed at the beginning of the decade, and the following definition of kitsch, cannot be underestimated: informed by his interest in the German author, the young intellectual began to consider the existence of a contradictory affinity between ersatz culture and folk art, a link that soon became one of his major concerns.

Greenberg's incisive definition of kitsch is still much quoted by international critics and scholars: kitsch is, as the author claims, «a product of the industrial revolution" and the direct result of «what is called universal literacy» (Greenberg [1939b]: 11); kitsch is the immediate answer to the new demands of the capitalist market and it is addressed to «those who, insensible to the values of genuine culture, are hungry nevertheless for the diversion that only culture of some sort can provide» (Greenberg [1939b]: 12). Kitsch's main source of images and clichés is the avant-garde, its ideas and representations: governed by the totalitarian ideology and the capitalist logic, this modern phenomenon is a passive mirroring of high cultural values, whose primary impulse is to assimilate the avant-garde's images and contents in order to become its trivial surrogate; as Greenberg claims, kitsch draws upon «the debased and academicized simulacra of genuine culture» (Greenberg [1939b]: 12; Greenberg, Schneller [2017]: 21-25). Because of its inner capacity to parody Western society's traditions and precepts, kitsch immediately became the preferred vehicle through which the totalitarian states could propagandize their own political values and repressive cultural standards. Greenberg's concerns about the use of kitsch by the totalitarian regimes as the primary medium for the manipulation of people's choices and preferences, were clearly mediated by Brecht's work but also influenced by the publication of new researches about the Nazi's propaganda. During that time, Greenberg's study of the Brechtian work went hand in hand with the translation of The Brown Network: The Activities of the Nazi in Foreign Country (Das braune Netz: Wie Hitlers Agenten im Auslande arbeiten und den Krieg vorbereiten, 1936), published in New York in 1936 and edited by W.F. Hare. As Greenberg wrote in a letter date-stamped December 14, 1936, during that time he was in charge of translating «half a German book about the Nazi for Burt Hoffman, who's gone into publishing on his own» (Greenberg, Van Horne [2000]: 148; O’Brian [1988]: XX; Goldfarb Marquis [2006]: 30; Greenberg, Schneller [2017]: 24). Between 1938 and 1939, after the publication of his review of Brecht's A Penny for the Poor and before Avant-Garde and Kitsch, Greenberg was working on a second and longer article on the German writer: according to an additional letter (January 16, 1939), at that time the critic already finished the piece on Brecht and submitted it to Philip Rahv, one of the editors of "Partisan Review", who suggested him 
to revise it and to focus on two main topics, «popular poetry, Stalinist politics»:

About Brecht - you'll disagree with my review [The Beggar's Opera - After Marx: Review of A Penny for the Poor by Bertolt Brecht]. As to my other piece, the article - it's about Brecht's poetry, not about himself. Of course, my consideration of his poems is inadequate, but I don't agree that it's ineffectual. But how can any good poetry be introduced adequately? Shall I, like you, give an impressionistic description of it? No. I must explain its public significance. As for [Philip] Rahv's remark, in rewriting the piece I shall have to follow more or less the same directives I started with: popular poetry, Stalinist politics. (Greenberg, Van Horne [2000]: 191-192)

The scrutiny of Greenberg's personal papers held by the Getty Research Institute, led to the identification of the mentioned paper, which can be recognized in a still unknown draft entitled Aspects of Bertolt Brecht (Greenberg [19381939?]). The article, twenty-two pages long, bears the signs of handwritten corrections and annotations, surely made by Greenberg before or after the submission to Rahv. Aspects of Bertolt Brecht was conceived as an analysis of Brecht's work and, at the same time, as an ideological and politicized intervention on the pervasive force of popular culture under late capitalism. Therefore, Greenberg's primary intentions were to examine in depth the prevailing popular culture narrative (not yet called kitsch) and the modern conditions of both visual and verbal art practices. Still today the relevance and significance of this unknown essay has not been acknowledged or recognized by scholars yet: on one side, the paper documents the strong interdependence between the critic's reflections on Brecht and the further definition of kitsch; but on the other, the essay enables to visualize Greenberg's critical methodology.

Given that Aspects of Bertolt Brecht is at the core of the critic's observations on the relation between high and low (popular) culture, namely the essential assumption at the basis of AvantGarde and Kitsch, the connection between the two essays is much stronger: we may state that
Aspects of Bertolt Brecht constitutes the primary genetic space of Avant-Garde and Kitsch. One persistent thread in Greenberg's early works is the tendency to combine or layer different drafts in order to create one complete essay: the germ of Avant-Garde and Kitsch can be traced back to an articulated process of selection and stratification of entire paragraphs from the piece about Brecht, then combined with other scatter notes that represent the first tentative definition of the main features of Western popular culture, finally designated with the word kitsch. Therefore, Aspects of Bertolt Brecht immediately became for Greenberg the arena for the experimentation with new crucial themes and for the development of a more effective vocabulary.

The main difference between the two essays concerns the importance given to Brecht's literary works: in the first one, the German author is the leading subject of Greenberg's reflections about the contradictory coexistence of high art with popular culture; in the second one, Avant-Garde and Kitsch, as the title immediately highlights, the main topic is the arduous survival of avant-garde art, oppressed by the rise of Nazi-Fascism and the emergence of new standards resulting from the modern homogenization of culture. As the leading contents of Aspects of Bertolt Brecht display, it was Greenberg's ambition to demonstrate and then analyze the extensive interdependence between Brecht's poetry and the cultural consequences of the preeminence of the capitalist market. By positioning the German author's thoughts in relation to their social and political context, it was possible for Greenberg to determine the dialectical correlation between progressive/avantgarde art and popular culture. Therefore, the analysis of Brecht's work gradually became an open arena in which the problem of kitsch could be defined and qualified ${ }^{2}$. Considering the future

${ }^{2}$ Greenberg's interest in the social and political context that gave rise to kitsch, was shared with other American intellectuals, especially with Meyer Schapiro. It is quite impossible to underestimate Schapiro's contribution to the definition of an effective critical methodology rooted in the Marxist model of thinking and writing, and com- 
definition of kitsch as a crossbreeding of popular culture and vanguard forms, Greenberg's interest in Brecht comes with no surprise: in the opening pages of the essay, the critic immediately emphasized an original feature of Brecht's literary works, that is the experimental interaction between a refined style and an informal register. As Greenberg underlined, this original coexistence of both types of rhetoric, a quite prominent feature of Brecht's literary work, was deeply rooted in the tradition of the German folk ballad: namely a cultural hybrid, it provided an effective example of the combination and stratification of two opposing genres of literary structures, the folklike rhyme and the lyric poetry, and it soon became the perfect testing ground for Brecht's literary practices. According to Greenberg's essay, this creative position required to be interpreted as a political gesture: Brecht's insistence on the colloquial lexicon was not a mean to attract a mass audience, as many misinterpreted it, but was the clear sign of his aversion for the bourgeois set of beliefs and general cultural attitude.

At that time, the emphasis on the synthetic character of Brechtian writing soon became Greenberg's leading interest: two opposed elements, the popular-folk culture and the vanguard, managed to coexist in an original hybrid creature, that is Brecht's art. These observations, at the core of Greenberg's essay, went hand in hand with other considerations about the relationship between folk art and ersatz culture: six groups of loose notes bridge the gap between Aspects of Bertolt Brecht and the forthcoming Avant-Garde and Kitsch, mediating between the two essays (Greenberg [1938-1939]). The scholars have not properly

patible with the issues and questions raised by the historical and formal development of the visual arts across the centuries. As two of Schapiro's early essays clearly exhibit (Schapiro [1936]; Schapiro [1937]), the critic read the cultural and political turmoil of those years through the lens of Marxist traditional assumptions about the relation between class and capital, base and superstructure. Apropos of Schapiro's critical methodology and frame of references, see Hemingway [1994]; Hills [1994]; Noyes-Platt [1999]: 157-159; Froio [2018]: 101-109. acknowledged this aspect of Greenberg's interest in ersatz culture yet: according to these notes, the critic was deeply immersed in the reconstruction of the gradual conversion of folk art into kitsch, a topic that is not fully developed in Avant-Garde and Kitsch, conceivably because the critic preferred to expand his considerations on the origins and progression of avant-garde $\mathrm{art}^{3}$.

At the very beginning of his reflections on Brecht, Greenberg conceptualized the polarity between folk art and high-elitist culture, which clearly foreshadowed the future dichotomy between kitsch and vanguard. The critic wrote down that native art had to be considered as the immediate precursor of kitsch and as the main opponent to high culture before the emergence of capitalism. Still untouched by the development of the capitalist market, the rural communities could find diversion and entertainment only in the native traditions: the forms and substance of this kind of art were simple and familiar, deeply rooted in the farmers' habits and way of living. But with the urbanization of the masses and the spread of literacy, these social and cultural circumstances drastically changed: the traditional background, the country, was replaced by the city, and the rural communities were gradually employed by the industries. The change of both the social system and the working context went hand in hand with the development of new forms of diversion: since the folklike traditions could not satiate an unprecedented appetite for diversion, the masses searched for new sources of entertainment; according to the supply and demand mechanism, at the core of the capitalist system, the cultural market immediately provided a suitable set of commodities. An increasing appetite for new cultural products character-

\footnotetext{
${ }^{3}$ Alice Goldfarb Marquis has already stressed the presence of some peripheral informal documents, mainly notes and other scattered sheets of paper, related to Greenberg's gradual conceptualization of kitsch art and preserved by the Getty Research Institute. Despite her emphasis, these documents have not received the proper attention they actually deserve. See Goldfarb Marquis [2006]: 52-54.
} 
ized the modern era: commercial literature, radio programs, Hollywood movies, catchy music etc. soon became the new attractions for the working class community. These genres of art, popular and inexpensive, were gradually replacing the native art expressions, creating, as Greenberg noticed, the first form of universal, in the sense of global, culture. The peasant only apparently abandoned his native traditions: instead, he could recognize the same pleasant design and pattern in the commodities the capitalist market was now offering him in exchange for money. For this reason, kitsch couldn't be defined as a new form of art: it exploited the preexisting cultural expressions and strategically converted them into a commodity, suitable for the routines and cultural level of the working class. Greenberg noted that several elements that characterized Russian folk art (i.e. the enjoyable use of colors, the pleasing spatial organization and the figures arrangement) simply migrated from the traditional sacred images to create the exemplary scheme of the so-called Socialist Realism, the official art style of Soviet Russia under Stalinist totalitarianism. For the very first time in history, the peasant found himself deeply attracted to this genre of images rather than to the traditional icons: more gratifying and pleasant, these commodities satiated the spectator's sheer appetite for thrill and emotion, a kind of diversion that the native religious images were unable to provide.

\section{DWIGHT MACDONALD'S PLAGIARISM AND THE GERM OF AVANT-GARDE AND KITSCH}

According to the already mentioned letter written by Greenberg and addressed to his friend Harold Lazarus, Aspects of Bertolt Brecht, once submitted to the Partisan Review's editorial board, didn't satisfy Philip Rahv's expectations (Greenberg, Van Horne [2000]: 191-192). Therefore, the author abandoned his project but attempted to outline a new article few years later (1941), entitled Bertolt Brecht's Poetry, largely based on the previous draft and then finally pub- lished by "Partisan Review" (Greenberg [1941]).

Around February 1939, Greenberg unfortunately noticed that Aspects of Bertolt Brecht, already proposed to the magazine, had been plagiarized by Macdonald, who used it as the starting point for his new piece, Soviet Society and Its Cinema (Macdonald [1939]). Greenberg confided his suspects to Lazarus (February 16, 1939):

Did you read Macdonald's piece yet? I smelled something familiar about it, something that came from my piece on Brecht's poetry [Aspects of Bertolt Brecht], and sure enough it turns out that the other editors of the magazine objected to Macdonald that he had taken my ideas. He himself told this to Sol [Greenberg, Clement's brother]. (Greenberg, Van Horne [2000]: 194)

Notwithstanding his doubts, Greenberg finally decided to write a missive addressed to the editor: "I sent him a long letter pointing out certain things I disagreed with in his article and my own ideas on the subject - nothing at all to do with his having taken them, for I'm still not sure that he has, or if he has, he's garbled them beyond recognition» (Greenberg, Van Horne [2000]: 194; Jones [2005]: 22). As Greenberg later reported in the same missive, Macdonald not only replied to his letter but encouraged him to use it as the foundation for a new essay: "So he answered by saying that he thought my letter was wonderful and that he wants to publish it as an article in the next "Partisan Review" [issue]» (Greenberg, Van Horne [2000]: 194). According to a survey of Greenberg's personal papers, the critic preserved the aforementioned missive: the original letter is eight pages long, typewritten and annotated, and dated February 6, 1939 by the author himself (Greenberg [1939]). As the pages exhibit, Greenberg took notes in the margins of the document: the visible signs of a process of revision demonstrate that the missive was actually used as a draft for a further plan, conceivably the arrangement of the forthcoming Avant-Garde and Kitsch. Several elements confirm this hypothesis: besides the proximity of the two letters, the first one addressed to Macdonald (February 6, 1939) and the second one to Lazarus (February 16), the literal similarity 
between the former missive and several passages of Avant-Garde and Kitsch is quite unmistakable. If Aspects of Bertolt Brecht represents the former draft of Avant-Garde and Kitsch, as the previous paragraph proved, then the letter addressed to Macdonald clearly stands between the two essays. According to this theory, the missive should be defined as a meaningful palimpsest: the overlappings of several notes and amendments, especially the erasure of the second person singular, formerly the direct reference to the addressee, demonstrate that Greenberg resumed the letter after Macdonald's encouraging answer and considered it as a suitable working space.

Since the beginning of the letter, Greenberg took up the questions raised by Macdonald in his essay, Soviet Society and Its Cinema, but at the same time he dissented from his opinion, shared with Kurt London, about the masses' predilection for commercial culture and their rejection of the modernist art movements, as Cubism and abstract art in general. Despite the shared assumption that the emergence of a new counterculture was threatening the survival of the avant-garde, Greenberg disagreed with Macdonald's statement about the nature of the relationship between the ruling class and the masses: according to the editor's viewpoint, the historical development of Western art moved forward without coming into contact with the masses and strictly followed its own path, dictated by the social and economic interest of the middle class. As Greenberg asserted in the letter, for too long the vicarious influence of the working class on the direction of Western art had been neglected by the leftist intellectuals: Macdonald's piece perfectly exemplified the rooted inclination to give a one-sided perspective on a much more complicated and multifaceted phenomenon. In Greenberg's opinion, for centuries the dominant class had exerted a pressure on the masses by imposing a raw version of its own cultural values and forms of entertainment. These two main strands, high art and popular art, had always been entwined, Greenberg noted, and a German word, kitsch, here used for the very first time by the critic, represented the more suitable expression to define this complex crossbreeding phenomenon.

Following on from this crucial argumentation, Greenberg tried to provide an explanation for the masses' attitude towards art, especially their predilection for kitsch instead of other cultural expressions, like Cubism or Fauvism. Macdonald, still quoting from London's volume, stated that the Russian uncultivated working class favored the realism of Ilya Repin's paintings and disdained Picasso's still lives because it was instructed to do so by the regime. But the Western school system, Greenberg replied, taught to respect the so-called classical art, like Rembrandt's masterpieces or Ingres's paintings, and to avoid trivial and commercial styles, such as Maxfield Parrish's affected art. The reason why the masses were attracted to kitsch depended on the formal characteristics of kitsch itself: a commodity produced by the capitalist market and perfectly planned to beckon the uncultivated masses, kitsch had no competitors, it immediately gratified the working class' tastes and provided inexpensive sources of amusement. The audience's reaction to kitsch was both sympathetic and deeply impulsive: since it was not mediated by cultural constructs, the relationship between consumer and commodity was strictly instinctive and immediate.

In addition, Greenberg did not agree with Macdonald and London about a further issue: according to both critics, Nazi-Fascism and Stalinism represented the roots of the phenomenon of kitsch, and consequently the masses were only passive victims of the regimes' persuasive propaganda against the avant-garde. Greenberg's opinion was exactly the opposite: the dictators reinforced their supremacy by satisfying a collective demand and providing the working class with its object of desire, i.e. kitsch commodities. The letter argues already for what was to become Greenberg's main concern and commitment as an art critic: following the Marxist assumptions about the mechanism of base and superstructure, Greenberg diverged from Macdonald's argumentation and, instead of blaming the totalitarian regime's high control over art and education, 
stressed the connection between social-economic imbalance and cultural dissolution. As the critic asserted both in the missive and in the essay, during the last decades, Western society gradually became uncertain of its own values and beliefs: in these particular conditions of ideological confusion and collective weariness, the capitalist system took advantage of the masses' ignorance and poverty, and presented itself as the only possible solution to their despair by offering means of instant satisfaction and temporary joy.

\section{CONCLUSION}

As we tried to highlight, Greenberg's letter to Macdonald shares certain fundamental assumptions with the forthcoming Avant-Garde and Kitsch: entire paragraphs are literally reproduced in the essay and several passages outline the main topics later pursued by the critic. Besides the several cross references, the two documents especially share the same conclusion: they both claim that the only solution to the decay of avant-garde art is the establishment of a socialist regimen. The following quotation comes from Avant-Garde and Kitsch:

Capitalism in decline finds that whatever of quality it is still capable of producing becomes almost invariably a threat to its own existence. Advances in culture, no less than advances in science and industry, corrode the very society under whose aegis they are made possible. Here, as in every other question today, it becomes necessary to quote Marx word for word.

Today we no longer look toward socialism for a new culture - as inevitably as one will appear, once we do have socialism. Today we look to socialism simply for the preservation of whatever living culture we have right now. (Greenberg [1939b]: 22)

In spite of his political ideology and declared faith in Socialism, Greenberg never believed in the messianic role attributed to the working class: he always doubted Trockij's prediction about a bright and rich cultural era governed by the dic- tatorship of the proletariat, mainly because he couldn't trust the idea of the potential intellectual superiority of the masses ${ }^{4}$. In the same way, Greenberg wasn't certain about Brecht's expectations for the forthcoming dismantle of the bourgeois system of values: he couldn't agree with the idea of an extreme cultural democratization controlled by the working class, who would finally have access to a cultural dimension that had always been limited to the aristocrats and the bourgeoisie ${ }^{5}$. Consequently Greenberg's assumptions were quite the opposite: as he declared in Avant-Garde and Kitsch and then, only one year later, in the following essay, Towards a Newer Laocoon (Greenberg [1940]), the avant-garde culture had always belonged to the middle class inteligencija, which soon became its social and economic base; but, with the gradual appearance of late capitalism, came a new era of cultural uniformity, misinterpreted as an unprecedented achievement of Western democracy ${ }^{6}$. In Greenberg's opinion, the working class' new cultural power constituted a threat to the survival of the avant-

${ }^{4}$ Apropos of Trockij's theory about the necessity of a «revolutionary mass base», see Trockij, Siegel [1972]: 104-114; about the critical reception of Trockij's ideas by the New York intellectuals, see Orton, Pollock [1981]: 214-217.

${ }^{5}$ Greenberg's admiration for Brecht seems quite contradictory once we have evaluated their divergent perspectives on modern art: since his first essays for "Partisan Review", Greenberg had always advocated abstractionism and condemned representational art, especially Socialist Realism, the one notably fostered by Brecht.

${ }^{6}$ Greenberg reinforced his cultural and political stance with his later essay, Towards a Newer Laocoon, generally regarded as the extension of Avant-Garde and Kitsch. The author here displayed an elitist point of view about the fate of art by stressing the connection between avantgarde art (i.e. abstract art) and its exclusive intellectual audience. About Greenberg's cultural elitism see Goldfarb Marquis [2006]: 57-58; in relation to Towards a Newer Laocoon, see Greenberg, Schneller [2017]: 27-30; about Greenberg's cultural pessimism, see ibid: 35-37. An extensive analysis of Greenberg's Laocoon is provided by Froio [2020], a monographic study focused on the scrutiny of the essay's primary drafts held by the Getty Research Institute. 
garde: the bourgeois élite, a culturally progressive and wealthy ruling-class, was now replaced by a new unintelligentsia, a reactionary and indigent social group, which was actually destroying the Western cultural heritage by demanding a massified pseudo-art. The traditional social basis of the avant-garde, the middle class, found itself definitively pushed out and banished. Greenberg's personal answer to the modern cultural decline was extremely clear: he truly believed that the avantgarde required to be isolated from the capitalist voracity and from the sight of the culturally undeveloped masses; only the enlargement of the distance between the two social classes, the middle and the working class, and their respective art forms, would prevent the definitive assimilation of the avant-garde into kitsch ${ }^{7}$.

Considering Greenberg's negative opinion about a future working-class sovranity, the one predicted by Marxism, his conclusion that only a Socialist government could be the answer to the decline of Western culture, seems quite contradictory. Therefore this persistent calling upon Socialism, both in the essays and in the letter to Macdonald, instead of a demonstration of Greenberg's belief in Marxism, should be considered as a sort of deus ex machina, a narrative expedient that at the time constituted the best suitable explanation for the rising power of Nazi-Fascist ideology and its subsequent cultural consequences. Greenberg's remark, "we look to socialism simply for the preservation of whatever living culture we have right now» (Greenberg [1939b]: 22, author's italics), is quite significant: it is not difficult to posit a link between this statement and its probable source, most likely Rosa Luxemburg's known maxim «Socialism or Barbarism» (Luxemburg, Basso [1967]: 447; Clark [1961]: 78). Written immedi-

\footnotetext{
7 T. J. Clark in his essay entitled Clement Greenberg's Theory of Art, defined Greenberg's contradictory attitude towards art and politics as «Eliotic Trotskyism», meaning an original combination of Marxist stances with a conservative viewpoint, mainly inspired by T.S. Eliot's cultural perspective (Clark [1961]: 74). See also Leja [1993]: 222-225; about Greenberg's connection with T.S. Eliot, see Golub [1997].
}

ately after the outbreak of the First World War, these words clearly reflected Luxemburg's concern about the fate of both the international proletariat and the future of Western civilization, threatened by the primary diseases of the modern age, namely the capitalist economic system and the imperialist ideology. By 1939, at the eve of the Second World War, when Avant-Garde and Kitsch was conceived and then published, Luxemburg's sentence regained its original significance, especially for those who, like Greenberg, were looking for inspiration from the words of the leading Marxist theorists ${ }^{8}$. But, by indirectly referring to Luxemburg's aphorism, Greenberg implied something different: the choice remained the same, Socialism or barbarism, but the meaning of those two words inextricably changed. For Greenberg it was not an alternative between the Nazi-Fascist dominance and the future coming of the proletarian revolution: the alternative was between the final triumph of a misleading counterculture, inspired by the working class' cultural needs, namely the new potential social and political force of the future, as Luxemburg saw it; and the preservation of the only form of art that could be called progressive, politically independent and aesthetically autonomous: the avant-garde.

\section{REFERENCES}

Aaron, D., 1977: Writers on the Left: Episodes in American Literary Communism, Octagon Books, Oxford-New York.

Benjamin, W., 2016: Saggi su Brecht, ed. by R. Degrassi, Asterios, Trieste.

\footnotetext{
${ }^{8}$ At that time, Greenberg was extremely fascinated by Luxemburg's writings and shared this interest with the journal's editorial board. As a matter of fact, only one year before the publication of Greenberg's Avant-Garde and Kitsch, "Partisan Review" reprinted some of Luxemburg's letters addressed to her friend Sonia Liebknecht, which documented her life during the imprisonment in Lispia, then Wronke and Breslavia. Macdonald and Greenberg worked together on the translation of the missives, published in the Summer 1938 issue of the journal (Greenberg, Van Horne [2000]: 211).
} 
Benjamin, W., 1983: Understanding Brecht, ed. by S. Mitchell, and A. Bostock, Verso, London.

Bloom, A., 1986: Prodigal Sons: The New York Intellectuals and Their World, Oxford University Press, New York-Oxford.

Brecht, B., 1928-1931: Lopera da tre soldi, ed. by E. Castellani, Einaudi, Torino, 2015.

Brecht, B., 1933-1941: Una drammaturgia non aristotelica, in Scritti teatrali, Einaudi, Torino, 1975, I, pp. 121-173.

Brecht, B., 1934: Il romanzo da tre soldi, ed. by $\mathrm{R}$. Leiser, F. Fortini, Einaudi, Torino, 1979.

Brecht, B., 1975: Scritti sulla letteratura e sullarte, ed. by C. Cases et al., Meltemi, Milano, 2019.

Buhle, P., 1987: Marxism in the United States: Remapping the History of the American Left, Verso, London.

Camporesi, C., 1973: Il marxismo teorico negli USA, 1900-1945, Feltrinelli, Milano.

Chiarini, P., 1961: Lavanguardia e la poetica del realismo, Laterza, Bari.

Clark, T.J., 1961: Clement Greenberg's Theory of Art, in Fascina, F. (ed.), Pollock and After. The Critical Debate, Routledge, London-New York, 2000, pp. 71-86.

Cooney, T.A., 1986: The Rise of the New York Intellectuals: "Partisan Review" and Its Circle, The University of Wisconsin Press, Madison.

Cooney, T.A., 1995: Balancing Acts. American Thought and Culture in the 1930s, Twayne, New York.

Decter, J., et al., 1986: The Greenberg Effect. Comments by Younger Artists, Critics and Curators, “Arts Magazine", 64 (4), pp. 58-64.

Desideri, F., et al., 2005: Estetica e filosofia dell'arte: un'identità difficile, Albo Versorio, Milano.

Donno, A., 1983: La "Questione comunista" negli Stati Uniti. Il Communist Party dal Fronte Popolare alla guerra fredda (1935-1945), Milella, Lecce.

Froio, C., 2018: A Quality of Jewishness. Ebraismo e modernismo nella critica di Clement Greenberg, Pontecorboli Editore, Firenze.

Froio, C., 2020: Verso un Laocoonte modernista. Temi, immagini e contesti del Laocoonte di Clement Greenberg, Pontecorboli Editore, Firenze.
Gilbert, J.B., 1968: Writers and Partisans: A History of Literary Radicalism in America, Wiley, New York.

Goldfarb Marquis, A., 2006: Art Czar. The Rise and Fall of Clement Greenberg, MFA Publications, Boston (MA).

Golub, A.M., 1997: Towards a Newer Critique. The Missing Link: The Influence of T.S. Eliot's UltraConservative Criticism on Clement Greenberg's Early Rhetoric and Themes, "Art Criticism", 12 (1), pp. 5-37.

Greenberg, C., 1928-1932: Clement Greenberg Papers, Letters to college friend Harold Lazarus, Getty Research Institute, Los Angeles (CA).

Greenberg, C., 1933-1937: Clement Greenberg Papers, Letters to college friend Harold Lazarus, Getty Research Institute, Los Angeles (CA).

Greenberg, C., 1938-1939?: Clement Greenberg Papers, Typewritten corrected draft of the essay Aspects of Bertolt Brecht, Early Writings, 1920s-1940s, Getty Research Institute, Los Angeles (CA).

Greenberg, C., 1938-1939: Clement Greenberg Papers, Handwritten notes, Early Writings, 1920s-1940s, Getty Research Institute, Los Angeles (CA).

Greenberg, C., 1939: Clement Greenberg Papers, Clement Greenberg's Letter to Dwight Macdonald, 6 February 1939, typewritten and annotated, Early Writings, 1920s-1940s, Getty Research Institute, Los Angeles (CA).

Greenberg, C., 1939a: The Beggar's Opera - After Marx: Review of A Penny for the Poor by Bertolt Brecht, in O'Brian, J. (ed.), Clement Greenberg. The Collected Essays and Criticism, Perceptions and Judgments, 1939-1944, The University of Chicago Press, Chicago (IL), 1988, pp. 3-5.

Greenberg, C., 1939b: Avant-Garde and Kitsch, in O'Brian, J. (ed.), Clement Greenberg. The Collected Essays and Criticism, Perceptions and Judgments, 1939-1944, The University of Chicago Press, Chicago (IL), 1988, pp. 5-22.

Greenberg, C., 1940: Towards a Newer Laocoon, in O'Brian, J. (ed.), Clement Greenberg. The Collected Essays and Criticism, Perceptions and 
Judgments, 1939-1944, The University of Chicago Press, Chicago (IL), 1988, pp. 23-38.

Greenberg, C., 1941: Bertolt Brecht's Poetry, in O'Brian, J. (ed.), Clement Greenberg. The Collected Essays and Criticism, Perceptions and Judgments, 1939-1944, The University of Chicago Press, Chicago (IL), 1988, pp. 49-62.

Greenberg, C., 2017: Écrits choisis des années 1940. Art et Culture, ed. by K. Schneller, Éditions Macula, Paris.

Greenberg, C., Van Horne, J. (ed.), 2000: The Harold Letters, 1928-1943. The Making of An American Intellectual, Counterpoint, New York, 2003.

Hemingway, A., 1994: Meyer Schapiro and Marxism in the 1930s, "Oxford Art Journal", 17 (1), pp. 3-29.

Hills, P., 1994: Meyer Schapiro, "Art Front", and the Popular Front, "Oxford Art Journal", 17 (1), pp. 30-41.

Jones, C., 2005: Eyesight Alone. Clement Greenberg's Modernism and the Bureaucratization of the Senses, The University of Chicago Press, Chicago (IL).

Kuspit, D.B., 1979: Clement Greenberg. Art Critic, The University of Wisconsin Press, Madison (WI).

Leitch, V.B., 1988: American Literary Criticism from the Thirties to the Eighties, Columbia University Press, New York.

Leja, M., 1993: Reframing Abstract Expressionism: Subjectivity and Painting in the 1940s, Yale University Press, New Haven-London.

Luxemburg, R., 1967: Scritti politici, ed. by R. Basso, Editori riuniti, Roma.

Macdonald, D., 1939: Soviet Society and Its Cinema, "Partisan Review", 6 (2), pp. 80-95.

Macdonald, D., 1960: Masscult e Midcult, ed. by M. Maraschi, Piano B, Prato, 2018.

Mecacci, A., 2014: Il kitsch, Il Mulino, Bologna.

Noyes-Platt, S., 1989: Clement Greenberg in the 1930s: A New Perspective on His Criticism, "Art Criticism", 5 (3), pp. 47-64.

Noyes-Platt, S., 1999: Art and Politics in the 1930s: Modernism, Marxism, Americanism. A History of Cultural Activism During the Depression Years, Midmarch Art Press, New York.
O'Brian, J., 1988: Introduction, in O'Brian, J. (ed.), Clement Greenberg. The Collected Essays and Criticism, Perceptions and Judgments, 19391944, The University of Chicago Press, Chicago (IL), 1988, pp. XVII-XXV.

Orton, F., Pollock, G., 1981: Avant-Gardes and Partisan Reviewed, in Fascina, F. (ed.), Pollock and After. The Critical Debate, Routledge, London-New York, 2000, pp. 211-226.

Ostrow, S., 1989: Avant-Garde and Kitsch, Fifty Years Later. A Conversation with Clement Greenberg, "Arts Magazine", 64 (4), pp. 56-57.

Ottanelli, F.M., 1991: The Communist Party of the United States: From the Depression to World War II, Rutgers University Press, New Brunswick-London.

Raphael, M., 1933: Proudhon, Marx, Picasso. Three Studies in the Sociology of Art, Humanity Press, New Jersey-London 1980.

Rubenfeld, F., 1997: Clement Greenberg. A Life, University of Minnesota Press, Minneapolis.

Schapiro, D. (ed.), 1974: Social Realism: Art as a Weapon, F. Ungar, New York.

Schapiro, M., 1936: The Public Use of Art, "Art Front", 2 (10), pp. 4-6.

Schapiro, M., 1937: Nature of Abstract Art, "Marxist Quarterly", 1 (1), pp. 77-98.

Solomon, M. (ed.), 1973: Marxism and Art. Essays Classic and Contemporary, A.A. Knopf, New York.

Trotsky, L., 1923: Literature and Revolution, ed. by W. Keach, Haymarket Books, Chicago 2005.

Trockij, L., Siegel, P.N. (ed.), 1972: Leon Trotsky on Literature and Art, Pathfinder, New York.

Trockij, L., 1923: Letteratura e rivoluzione, ed. by V. Strada, Einaudi, Torino, 1974.

Wald, A., 1987: The New York Intellectuals: The Rise and the Decline of the Anti-Stalinist Left from 1930s to the 1980s, University of North Carolina Press, Chapel Hill-London.

Wald, A., 2002: Exiles from a Future Time: The Forging of the Mid Twentieth-Century Literary Left, University of North Carolina Press, Chapel Hill-London. 